\title{
Systematic Technology Evaluation Program for SiC-based BWR Channel Box
}

Nuclear Technology

Research and Development

Prepared for

U.S. Department of Energy Campaign or Program T. Koyanagi, Y. Katoh Oak Ridge National Laboratory April 2019 M2FT-19OR020202061 



\section{DISCLAIMER}

This information was prepared as an account of work sponsored by an agency of the U.S. Government. Neither the U.S. Government nor any agency thereof, nor any of their employees, makes any warranty, expressed or implied, or assumes any legal liability or responsibility for the accuracy, completeness, or usefulness, of any information, apparatus, product, or process disclosed, or represents that its use would not infringe privately owned rights. References herein to any specific commercial product, process, or service by trade name, trade mark, manufacturer, or otherwise, does not necessarily constitute or imply its endorsement, recommendation, or favoring by the U.S. Government or any agency thereof. The views and opinions of authors expressed herein do not necessarily state or reflect those of the U.S. Government or any agency thereof. 



\section{SUMMARY}

Silicon carbide (SiC) -based accident-tolerant fuel (ATF) cladding of light water reactors (LWRs) has become a topic of great interest in nuclear material development since the Fukushima Dai-ichi Nuclear Power Plant accident. Extensive development of SiC cladding has identified benefits of the concept, including its inherent accident resistance and neutronic performance. Advancements achieved during the development of SiC-based ATF cladding have made it attractive for use in accident-tolerant cores of LWRs. In this document, we consider the use of SiC-based materials to replace the zirconium alloy used for the channel boxes of boiling water reactors. Both accident resistance and prevention of the bowing observed in current grades of channel boxes are needs driving the exploration of a new channel box system.

To provide a pathway for channel box development, this document lays out (1) a current technology overview, (2) the technology gap, and (3) a systematic technology evaluation plan. The objectives of the technology evaluation plan are to address key feasibility issues revealed by the knowledge gap analysis and to contribute to advancing the technology readiness level. Further development will be required in the technology implementation phase. The technology evaluations include understanding the behavior of channel boxes under both normal and off-normal conditions, identifying potential mitigation strategies for the issues if necessary, and improving channel box performance based on the knowledge obtained. The structure of the technology evaluation plan and each task are shown in Figure S.1. The knowledge gap analysis identified key research areas, including irradiation effects, hydrothermal corrosion, accident behavior, and design and manufacture. These are common issues between SiC-based channel boxes and SiC-based fuel cladding, although technical evaluations specific for the channel box components are required. This document also describes details of the technical feasibility evaluation methods and plans.

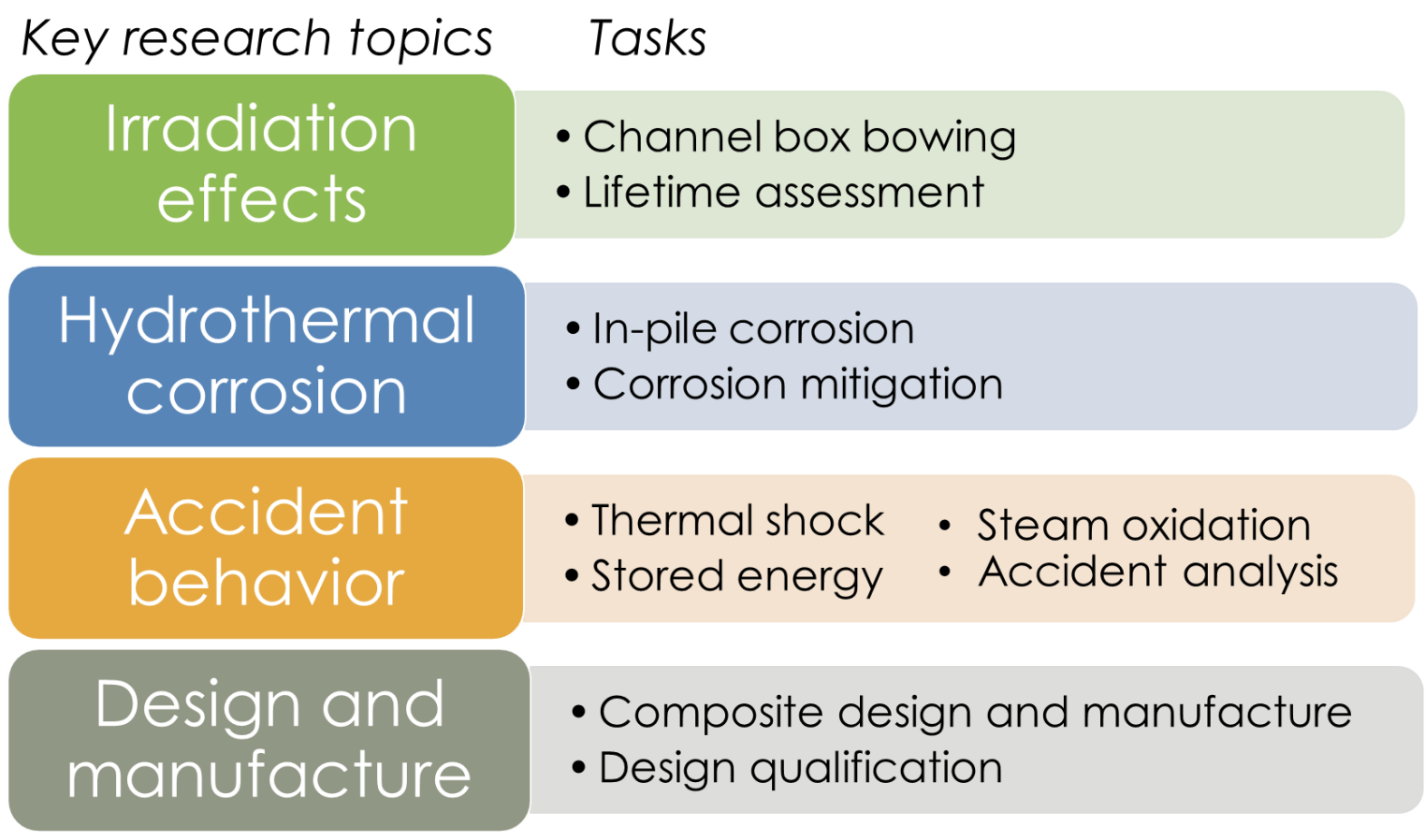

Figure S.1. A schematic illustration of the structure of a systematic technology evaluation program for the development of boiling water reactor SiC-based channel boxes. 


\section{CONTENTS}

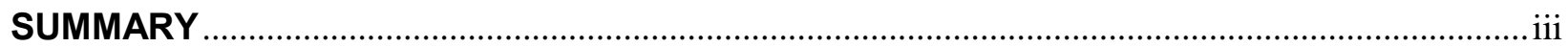

ACRONYMS

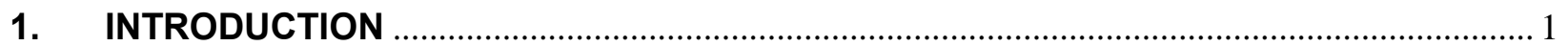

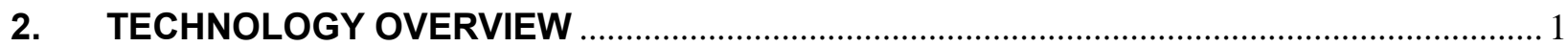

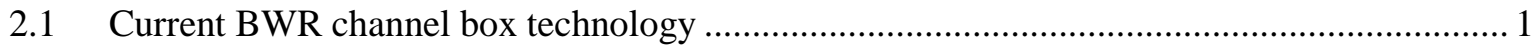

2.2 Current status of $\mathrm{SiC}$ material development ..................................................................... 2

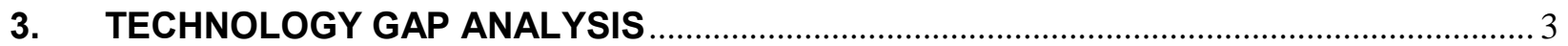

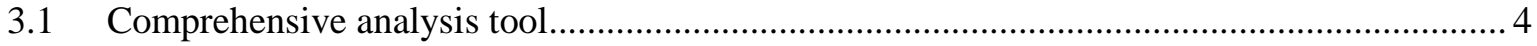

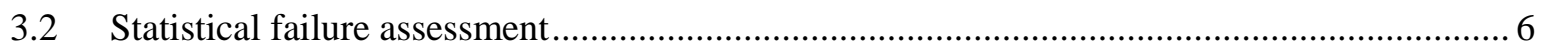

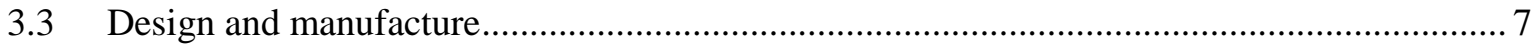

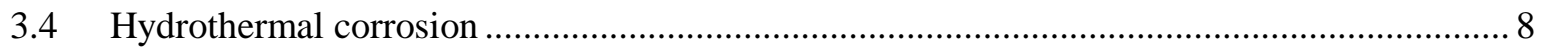

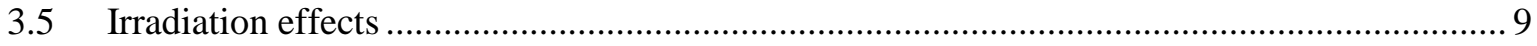

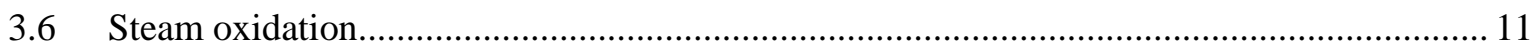

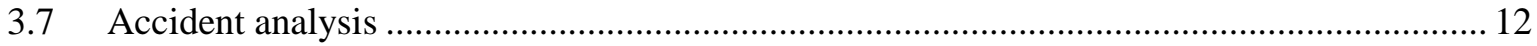

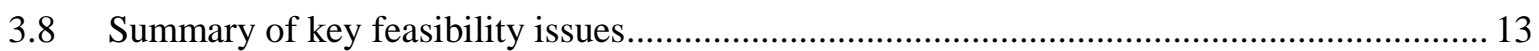

4. SYSTEMATIC TECHNOLOGY EVALUATION PROGRAM ................................................ 14

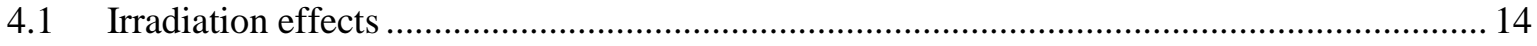

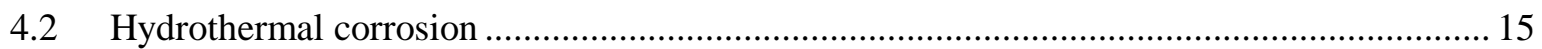

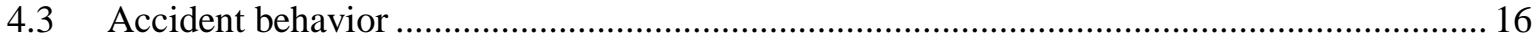

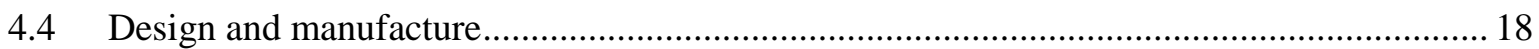

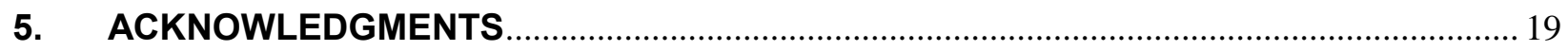

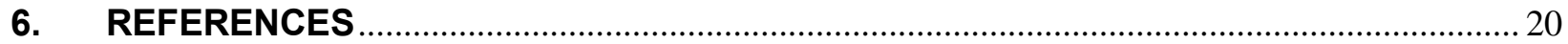




\section{FIGURES}

Figure 1. Schematic illustration of BWR channel box and channel box bowing.

Figure 2. Key research topics and potential issues for the development of SiC-based ATF channel boxes for BWR applications. Relevance among research topic and critical issue is indicated by "X".

Figure 3. Simulated (a) fast flux distribution and (b) channel box deformation and stress distribution [19]. Displacement is exaggerated for visualization purposes. ....

Figure 4. Experimental design of neutron irradiation experiments on SiC channel box in HFIR [20]. 6

Figure 5. Simulated stress distribution in CVI SiC/SiC composite channel box in a BWR [19].............. 7

Figure 6. SiC/SiC composite tube coated with chromium by electroplating [31] .................................... 9

Figure 7. Irradiation dose dependence of swelling of $\mathrm{SiC} \mathrm{[10]} \mathrm{...........................................................} 10$

Figure 8. Flexural behavior of CVI SiC/SiC composites reinforced with Hi-Nicalon Type S fibers

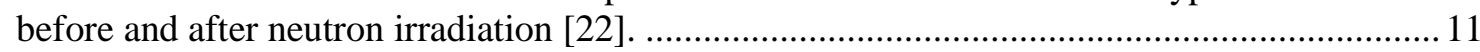

Figure 9. Neutron dose-dependent swelling and stored energy release of CVD SiC [41] ..................... 13 


\section{TABLES}

Table 1. Task structure, objectives, and outline in evaluations of irradiation effects............................... 15

Table 2. Task structure, objectives. and outline in hydrothermal corrosion evaluations........................... 16

Table 3. Task structure, objectives, and outline in accident resistance.................................................. 18

Table 4. Task structure, objectives, and outline in design and manufacture........................................... 19 


\section{ACRONYMS}

\begin{tabular}{|l|l|}
\hline Acronym & Identification \\
\hline ATF & accident-tolerant fuel \\
\hline BWR & boiling water reactor \\
\hline Cr & chromium \\
\hline CVD & chemical vapor deposition \\
\hline CVI & chemical vapor infiltration \\
\hline dpa & displacement per atom \\
\hline EBC & environmental barrier coating \\
\hline EPRI & Electric Power Research Institute \\
\hline HFIR & High Flux Isotope Reactor \\
\hline HWC & hydrogen water chemistry \\
\hline LWR & light water reactor \\
\hline NWC & normal water chemistry \\
\hline MIT & Massachusetts Institute of Technology \\
\hline ORNL & Oak Ridge National Laboratory \\
\hline SiC & silicon carbide \\
\hline SiC/SiC & SiC fiber-reinforced SiC matrix ceramic \\
\hline Zr & zirconium \\
\hline & \\
\hline
\end{tabular}




\section{SYSTEMATIC TECHNOLOGY EVALUATION PROGRAM FOR SIC-BASED BWR CHANNEL BOX}

\section{INTRODUCTION}

Accident-tolerant fuels (ATFs) and accident-tolerant cores of light water reactors (LWRs) have been topics of great interest in nuclear material development since the Fukushima Dai-ichi Nuclear Power Plant accident. Current LWRs use zirconium (Zr) alloys nearly exclusively as materials for fuel cladding and core structures. The fuels and core structures are vulnerable to catastrophic consequences in the event of certain loss-of-coolant scenarios that fall outside the design basis of the plant. This vulnerability is attributed primarily to the rapid oxidation kinetics of $\mathrm{Zr}$ alloys in a water vapor environment at very high temperatures, which results in the production of hydrogen and heat [1,2].

Recent extensive research and development in ATFs identified three potential options for LWR fuel cladding materials: coated $\mathrm{Zr}$, iron-chromium-aluminum-based alloys, and continuous silicon carbide ( $\mathrm{SiC}$ ) fiber-reinforced $\mathrm{SiC}$ matrix ceramic composites ( $\mathrm{SiC} / \mathrm{SiC}$ composites) [3]. $\mathrm{SiC} / \mathrm{SiC}$ composite fuel cladding is considered to provide outstanding passive safety features in beyond-design-basis severe accident scenarios [1,2]. The motivation for SiC-based fuel cladding is not only its accident tolerance but also its anticipated additional benefits compared with $\mathrm{Zr}$ alloys: smaller neutron absorption cross sections, general chemical inertness, ability to withstand higher neutron doses and higher temperatures, lack of progressive irradiation growth, and low induced activation/low decay heat [4]. Importantly, recent efforts toward the development of $\mathrm{SiC}$-based cladding have significantly advanced the fabrication of $\mathrm{SiC}$ composite tubes [5], in-pile performance analysis capability [6-8], and understanding of the thermomechanical properties of $\mathrm{SiC}$ tubes [9]. Although SiC-based cladding appears to be attractive, critical feasibility issues remain: (1) hydrothermal corrosion, (2) retention of gas leak tightness under service environments, (3) development of a fuel performance modeling capability, and (4) fabrication of fulllength tubes in sufficient quality [3]. These issues are being addressed worldwide.

The inherent accident tolerance of SiC-based material and advancement of the technology during ATF cladding development efforts have made it attractive for application in accident-tolerant cores of LWRs. More specifically, SiC-based material is being considered as a replacement for the $\mathrm{Zr}$ alloy used in the channel boxes of boiling water reactors (BWRs). In addition to accident resistance, a concern associated with the current $\mathrm{Zr}$-based channel box material is severe bowing during long periods of normal operation, which can create an obstacle to control blade insertion. Therefore, this is a serious safety issue. The introduction of $\mathrm{SiC}$ materials for use in channel boxes is a potential solution to this issue and may extend the service lives of channel boxes because $\mathrm{SiC}$ exhibits superior dimensional stability under irradiation at high doses [10].

The development of a SiC-based BWR channel box must address key technical challenges, including the effects of neutron irradiation, hydrothermal corrosion, accident resistance, and design and manufacture. In addition, the in-pile behavior of the material needs to be assessed by modeling to evaluate feasibility. This document aims to conduct a technology gap analysis of a SiC-based BWR channel box and provide a technology development plan. In this document, a strategy is pursued for drop-in replacement of $\mathrm{Zr}$ channel boxes by $\mathrm{SiC} / \mathrm{SiC}$ composite channel boxes with minimal changes in existing BWR design.

\section{TECHNOLOGY OVERVIEW}

\subsection{Current BWR channel box technology}

To minimize neutron absorption, LWR core structures, including the fuel cladding and BWR channel boxes, are mostly made of $\mathrm{Zr}$ alloys. The thin-walled, core-length square box (channel box) separates the 
control blade from the fuel assemblies to maintain stable neutronics in the core and to add structural mechanical stability [11]. The typical wall thickness is $2-3 \mathrm{~mm}$, depending on the reactor design $[11,12]$. It has been reported that the lifetime of a channel box is limited by several issues associated with the dimensional stability of Zr materials: (1) bulging due to irradiation creep under nonuniform applied pressure, (2) bowing due to differential irradiation growth caused by fast neutron flux gradients and differential hydrogen pickup at different locations, and (3) wall thinning due to excessive hydrothermal corrosion [11]. The channel distortion due to items (1) and (2) cannot exceed the clearance between the channel box and the inserted control blade, which is around a few millimeters. Otherwise, the channel distortion interferes with control blade insertion, as is schematically shown in Figure 1. The allowable channel box bowing depends on the reactor design, including the channel-to-channel gap and the control blade thickness. Channel distortion is a current issue and has been reported in recent years [11]. Obviously, this issue is more significant with increasing service time. Therefore, there is a potential economic benefit if channel boxes made of new materials (e.g., SiC/SiC composites) provide longer service life than current $\mathrm{Zr}$-based components.
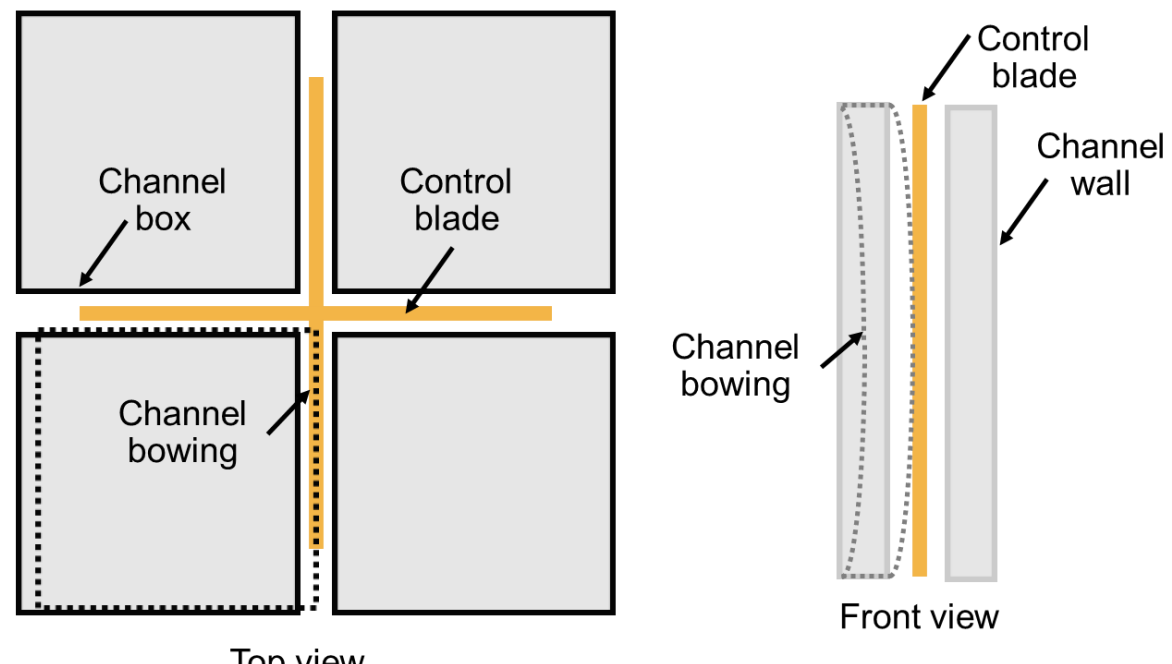

Figure 1. Schematic illustration of BWR channel box and channel box bowing.

\subsection{Current status of $\mathrm{SiC}$ material development}

$\mathrm{SiC} / \mathrm{SiC}$ composites have historically been investigated for high-temperature structural applications in fusion energy and advanced fission energy systems in which operational temperatures could reach $1000^{\circ} \mathrm{C}[13,14]$. Recently, development has focused on the relatively low application temperature of $\sim 300^{\circ} \mathrm{C}$ for ATF cladding of LWRs. Research and development in $\mathrm{SiC} / \mathrm{SiC}$ composites for various applications under different reactor operating conditions has accumulated irradiation data for many temperature and dose conditions [15]. These irradiation studies have revealed "nuclear-grade" $\mathrm{SiC} / \mathrm{SiC}$ composites consisting of a carbon interphase at the fiber and matrix boundary and relatively high-purity and highly crystalline $\mathrm{SiC}$ fiber and matrix [15]. These nuclear-grade $\mathrm{SiC} / \mathrm{SiC}$ composites exhibit limited degradation of their mechanical properties due to neutron irradiation up to $\sim 10$ displacements per atom (dpa) at a temperature range of $300-1300{ }^{\circ} \mathrm{C}[15]$.

$\mathrm{The} \mathrm{SiC} / \mathrm{SiC}$ composite processing routes that have been proven to produce radiation-resistant forms of composite materials are chemical vapor infiltration (CVI) [15] and SiC powder sintering represented by the NITE (nano-infiltration and transient eutectic phase) process [16]. CVI of $\mathrm{SiC} / \mathrm{SiC}$ composites is a 
mature technology that has extensively been studied for nuclear applications, compared with NITE $\mathrm{SiC} / \mathrm{SiC}$ composites, and has already demonstrated scale components with reasonable reproducibility. General Atomics has demonstrated $\sim 0.9 \mathrm{~m}$ long thin-wall SiC/SiC composite tubes [5]. CVI is a feasible method of producing thin-wall channel boxes, considering the limitation of the maximum thickness of the component due to the nature of the "infiltration" process. Hence, this document discusses a technology evaluation program for $\mathrm{CVI} \mathrm{SiC} / \mathrm{SiC}$ composite channel boxes.

BWR channel boxes made of SiC/SiC composites were earlier proposed by the Electric Power Research Institute (EPRI) [12,17]. The EPRI research program conducted feasibility evaluations of the SiC-based channel box system. The tasks included (1) neutronic analysis, (2) fragmentation resistance, (3) channel box bowing analysis, (4), steam oxidation, and (5) hydrothermal corrosion. The results of the neutronic analysis showed the economic benefit of the concept due to the lower neutron capture cross-section of $\mathrm{SiC}$ compared with $\mathrm{Zr}$. It was estimated that the fuel enrichment level for the $\mathrm{SiC}$ channel box system is decreased by approximately $0.1 \%$ for the equivalent core reactivity of the Zr-based system, translating to approximately $\$ 3$ million in savings per batch of fuel assemblies [12]. The experimental investigations associated with the EPRI research tasks (2)-(4) showed positive results, albeit preliminary ones. However, it was found that hydrothermal corrosion due to the BWR water chemistry is a critical feasibility issue. This document provides updated information regarding the technology gap analysis of SiC-based BWR channel boxes thanks to recent progress on $\mathrm{SiC} / \mathrm{SiC}$ composite development for various nuclear structural applications, especially for ATF cladding.

\section{TECHNOLOGY GAP ANALYSIS}

This technology gap analysis for BWR channel boxes follows the guidelines of the gap analysis of ATF cladding because of the similar technical hurdles [18]. Figure 2 shows key research topics and potential critical feasibility issues for the development of ATF SiC channel boxes. Common critical feasibility or performance issues for the development of cladding and channel boxes include coolant compatibility, cracking-induced failure, and accident tolerance. Expected causes of cracking-induced failure in the fuel cladding are thermal stress, irradiation-induced stress under a temperature gradient, and internal gas pressure. In the case of channel boxes, the neutron flux gradient may affect irradiation-induced stresses. Channel boxes are not affected by technology hurdles related to fuel compatibility and fission product retention, which are very critical for fuel cladding. Instead, channel box development needs to overcome bowing issues, as described in Section 2.1.

To address these potential issues, the key research topics for channel boxes include comprehensive analysis tools, statistical failure assessment, design and manufacture, hydrothermal corrosion, irradiation effects, steam oxidation, thermal shock resistance, and accident analysis. We reviewed each topic to conduct a technology gap analysis for channel box development. 


\begin{tabular}{|c|c|c|c|}
\hline \multirow{2}{*}{ Research topic } & \multicolumn{2}{|c|}{ Critical feasibility issue } & \multirow{2}{*}{$\begin{array}{l}\text { Critical performance } \\
\text { issue }\end{array}$} \\
\hline & $\begin{array}{l}\text { Coolant } \\
\text { compatibility }\end{array}$ & $\begin{array}{l}\text { Micro-cracking and } \\
\text { channel box bowing }\end{array}$ & \\
\hline $\begin{array}{l}\text { Comprehensive } \\
\text { analysis tool }\end{array}$ & & 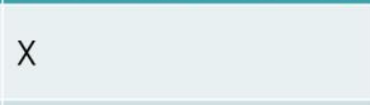 & $x$ \\
\hline $\begin{array}{l}\text { Statistical failure } \\
\text { assessment }\end{array}$ & & $x$ & \\
\hline $\begin{array}{l}\text { Design and } \\
\text { manufacture }\end{array}$ & $x$ & $x$ & $x$ \\
\hline $\begin{array}{l}\text { Hydrothermal } \\
\text { corrosion }\end{array}$ & $x$ & & \\
\hline Irradiation effects & $x$ & $x$ & $x$ \\
\hline Steam oxidation & & & $x$ \\
\hline Accident analysis & & & $x$ \\
\hline
\end{tabular}

Figure 2. Key research topics and potential issues for the development of SiC-based ATF channel boxes for BWR applications. Relevance among research topic and critical issue is indicated by "X".

\subsection{Comprehensive analysis tool}

As a channel box material, the transition from a $\mathrm{Zr}$-based alloy to a $\mathrm{SiC} / \mathrm{SiC}$ composite would be a revolutionary paradigm shift because of a lack of experience with the use of ceramic composite materials in nuclear reactors. Because of the impact associated with such a transition, new channel boxes made of $\mathrm{SiC} / \mathrm{SiC}$ composites must be carefully assessed via predictive performance modeling incorporating environmental effects on the material properties in BWRs. In addition, parametric analysis using the modeling will guide optimization of the channel box deign to maximize structural reliability and potential economic benefit. Therefore, the development of a reliable modeling tool to predict the response of channel box behavior to reactor environments is a critical task. The modeling will require both a physicsbased understanding of material behavior and a materials property database as input parameters of the model. Extensive key physical and mechanical properties of neutron-irradiated $\mathrm{SiC} / \mathrm{SiC}$ composites have been obtained from previous research for advanced reactor applications [15] and are available for modeling. They include elastic, thermal, and mechanical properties.

One of the most important phenomena to be modeled is channel box distortion, as explained in Section 2. Only limited analysis of the in-pile behavior of SiC-based channel boxes has been conducted at this time because of the relatively new concept. Singh et al. analyzed the response of CVI SiC/SiC composite channel boxes to BWR irradiation environments with heat and neutron flux gradients using a finite element method (Figure 3a) [19]. The modeling results showed significant bowing of the channel box with a lateral displacement greater than $6.5 \mathrm{~mm}$ after 11 days of operation if it remains unconstrained. The lateral bending of the channel box decreases throughout reactor operation leading to straightening of the channel box in the absence of irradiation creep. The lateral displacement also depends on mechanical boundary condition. In the case that top and bottom of the channel box are constrained, significant distortion and stress are expected (Figure $3 b$ ). The bowing was due to temperature- and neutron-dosedependent swelling of $\mathrm{SiC}$. Since time-dependent channel deformation under irradiation with temperature and flux gradients is a complex process, this modeling study requires experimental validation. In addition, a high-fidelity model of fast neutron distribution within the core is important. Full-core reactor analysis of 
the time-dependent dimensional stability and stress state of the entire channel box is also necessary, using an established modeling tool.

(a)

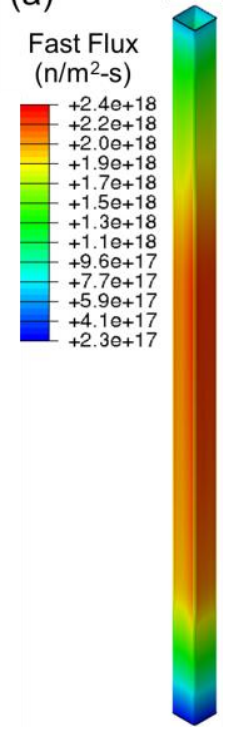

(b)

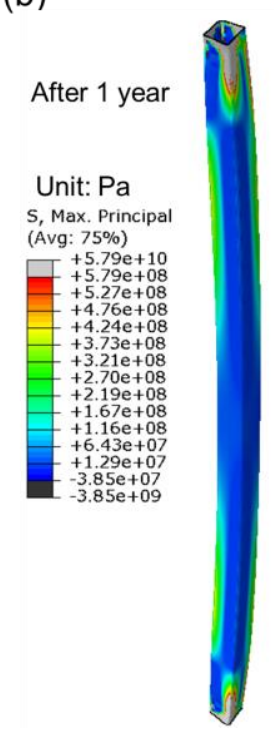

Figure 3. Simulated (a) fast flux distribution and (b) channel box deformation and stress distribution [19]. Displacement is exaggerated for visualization purposes.

Experimental investigation of channel box bowing has begun at Oak Ridge National Laboratory (ORNL) to validate modeling results or to refine a modeling methodology [20]. The study will conduct neutron irradiation of a miniature channel box with dimensions of $30 \times 30 \times 380 \mathrm{~mm}$ and a $1.25 \mathrm{~mm}$ wall thickness in the High Flux Isotope Reactor (HFIR) at ORNL. The test material will be a CVI SiC/SiC composite made by General Atomics. The experimental setup is shown in Figure 4. Because of the significant neutron flux gradient within the specimen, it is expected that a maximum of $\sim 0.6 \mathrm{~mm}$ lateral channel box bowing will occur after about 24 days of irradiation based on the modeling. The experimental investigation of the channel box bowing will provide critical input for the model validation. 


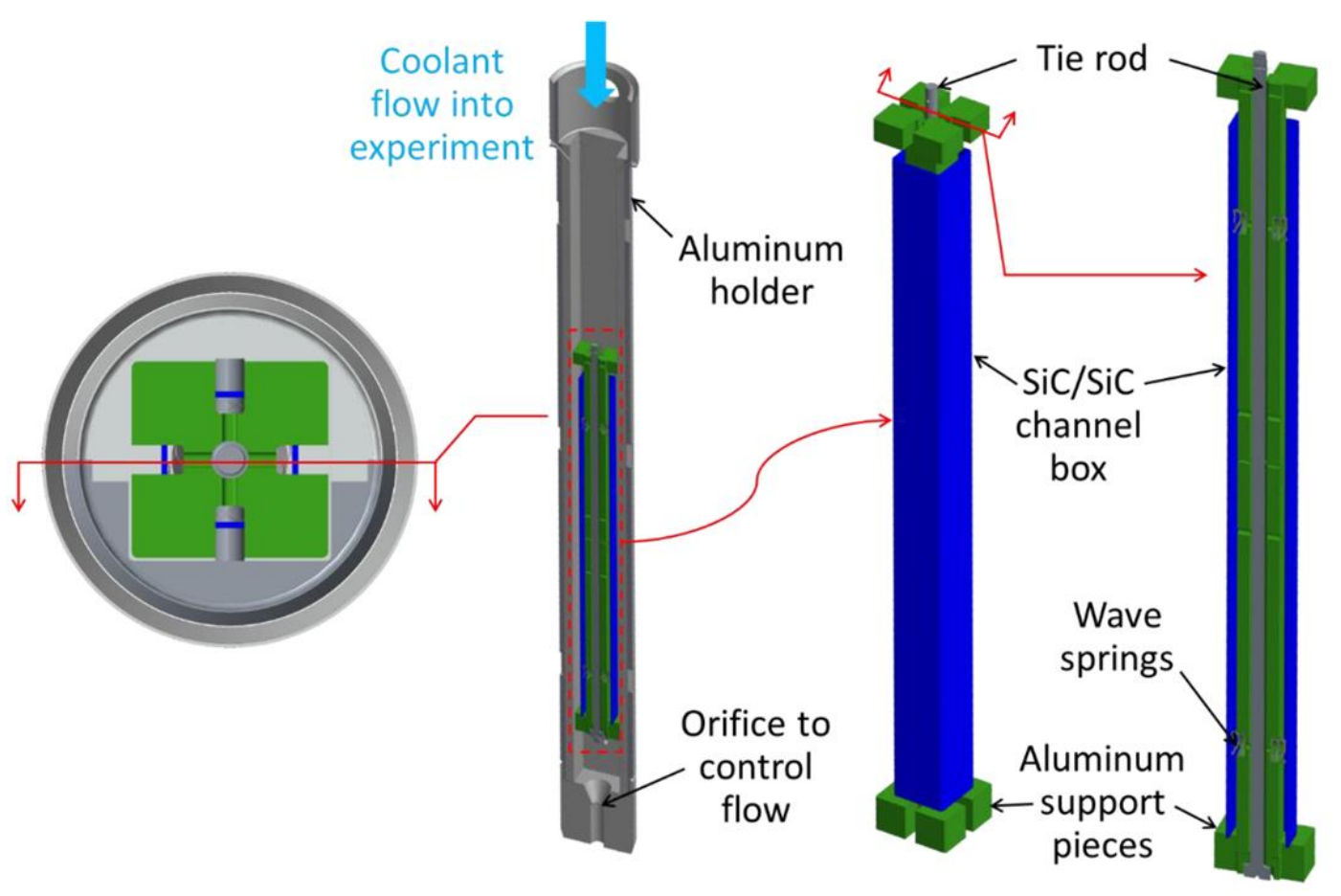

Figure 4. Experimental design of neutron irradiation experiments on SiC channel box in HFIR [20].

\subsection{Statistical failure assessment}

The $\mathrm{SiC}$ channel box is expected to receive a certain level of stress under normal operating conditions because the flux gradient will cause differential swelling strain within the component. Failure of the component needs to be statistically evaluated for component performance assessment. A definition of failure here is likely to be matrix cracking stress, which is nearly equal to proportional limit stress. Matrix cracking enlarges the surface area of the material and potentially exposes the fiber and interface, resulting in degradation due to hydrothermal corrosion and steam oxidation [2]. Modeling of the in-pile behavior of a $\mathrm{SiC}$ channel box by Singh et al. showed that the swelling gradient caused a maximum tensile stress of $49 \mathrm{MPa}$ at the lower corner of the channel after 54 days of operation. The stress decreases with increasing operation period, as shown in Figure 5. The maximum stress expected after 54 days is around half the reported proportional limit tensile stress of $93 \mathrm{MPa}$ obtained from thin-wall CVI SiC/SiC tube specimens [21]. Considering the reported standard deviation of $6 \mathrm{MPa}$, irradiation-induced cracking appears to be insignificant at low neutron doses $(<\sim 10 \mathrm{dpa})$ at which the mechanical degradation as a result of irradiation is limited [22]. 


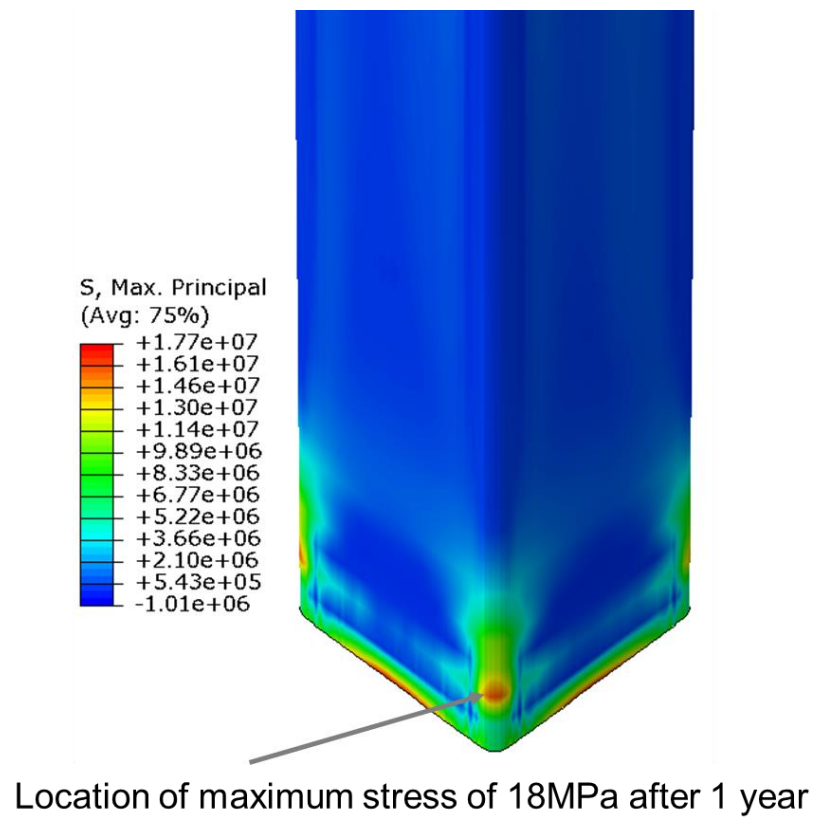

Figure 5. Simulated stress distribution in CVI SiC/SiC composite channel box in a BWR [19].

\subsection{Design and manufacture}

The $\mathrm{SiC} / \mathrm{SiC}$ composite-based channel boxed should be designed as a drop-in replacement for existing fuel assemblies to minimize modification of existing reactors; $\mathrm{SiC} / \mathrm{SiC}$ composite-based channel boxes should use dimensions similar to those of current $\mathrm{Zr}$-based channel boxes (e.g., $140 \mathrm{~mm}$ cross-sectional width, $3 \mathrm{~mm}$ wall thickness, and $3.7 \mathrm{~m}$ height [23]). This kind of thin-wall box-shaped component has been fabricated using CVI technology already. A section of a CVI SiC/SiC composite channel box has been demonstrated. The size of the largest such component reported was a $10 \mathrm{~cm}^{2}$ cross-section, a wall thickness of approximately $1.5 \mathrm{~mm}$, and length of $50 \mathrm{~cm}$ [12]. Hyper-therm High Temperature Composites Inc. (presently Rolls-Royce High Temperature Composites) fabricated this component [24]. For a CVI process, manufacturing a full-size channel box will require a large production facility that achieves adequate uniformity in temperature distribution and reactant flow conditions along the full channel box length, which is technically not difficult but requires capital investment. General Atomics has recently built such a CVI furnace for production of full-size fuel cladding. The channel box and cladding development efforts will leverage achievements and knowledge from each other in processing large components by CVI.

Although geometries of the SiC-based channel box should be similar to those of the current channel box, there is room to optimize channel box design. For example, a Zr-based channel box has increased wall thickness in areas of high stress concentration [11]. This kind of geometrical optimization process should be different between the $\mathrm{Zr}$ - and $\mathrm{SiC} / \mathrm{SiC}$ composite-based boxes because the material limiting factors will be different. In addition, the composite microstructure needs to be specifically optimized for the channel box application. The microstructural parameters include fiber architecture, porosity, surface roughness, fiber volume fraction, and thickness of the carbon interface. This optimization will be conducted using a comprehensive analysis tool (see Section 3.1). Therefore, the development of a comprehensive analysis tool is essential not only for understanding in-pile behavior but also for optimization of the channel box design. 
Development of a test method standard and a material code for the $\mathrm{SiC} / \mathrm{SiC}$ composite to regulate the design and manufacture of the channel boxes will be required for the licensing process. The standard ASTM C1793-15, "Guide to the Development of Specifications for Fiber Reinforced Silicon Carbide Composites for Nuclear Applications," provides general guidance for developing a detailed material specification for $\mathrm{SiC} / \mathrm{SiC}$ composite core components [25]. It guides consideration of composite constituents and structure, physical and chemical properties, mechanical properties, thermal properties, performance durability, methods of testing, material and fabrication processing, and quality assurance. The material and design qualification activities specific to the channel box application are currently missing.

\subsection{Hydrothermal corrosion}

Hydrothermal corrosion under normal operation is recognized as a critical feasibility issue for the development of SiC/SiC LWR cladding [3]. The same is true for channel box development, because the same coolant is used among the cladding and the channel boxes. BWRs use high-purity water as the primary coolant for steam production. The BWR normal water chemistry (NWC) condition has significant oxygen activity due to radiolysis, which causes issues for reactor core-structures. Some examples include corrosion and stress corrosion cracking of metallic materials. The amount of oxidant in the NWC is $\sim 200 \mathrm{ppb}$ in the recirculation line and several hundred ppb in the core region [26]. The water chemistry was modified to mitigate these materials issues, resulting in development of hydrogen water chemistry (HWC) with hydrogen injection and addition of zinc and noble metals [27]. Currently, BWRs operate with HWC worldwide [26].

$\mathrm{SiC}$ recession as a result of corrosion in high-temperature water leads to (1) thickness losses in channel boxes that could affect structural robustness and reliability and (2) deposition of unwelcome corrosion products in the water circuit. Therefore, it is essential to quantify the rate of $\mathrm{SiC}$ recession under operating environments with both NWC and HWC. The kinetics of SiC recession in hot water is governed by a surface oxidation reaction (silica formation), because once silica forms on $\mathrm{SiC}$ under hydrothermal conditions, it readily dissolves in water. Therefore, it is also important to consider that the silica concentration in the reactor coolant can reach its solubility limit, and then the silica will deposit in the relatively cold regions of the coolant loop [28].

Critical data for in-pile hydrothermal corrosion of a high-purity chemical vapor deposition (CVD) overcoating on a SiC/SiC composite were obtained using the Massachusetts Institute of Technology (MIT) reactor [12]. The material was exposed to BWR NWC under neutron irradiation for 2.5 months. The tested CVD SiC overcoating layer exhibited significant recession. The various specimens tested experienced up to $20 \%$ mass loss as a result of corrosion. These results give rise to concerns about the feasibility of SiC-based BWR channel boxes with NWC. In contrast, only a minor weight loss was observed after an MIT reactor in-pile corrosion test using pressurized water reactor environments with hydrogen injection, indicating the oxidizing environment caused the corrosion issue [12]. Current understanding of in-pile hydrothermal corrosion of $\mathrm{SiC}$ is immature because of limited in-pile data and because most of the tests were conducted using an autoclave [3]. The current understanding of hydrothermal corrosion of SiC is that NWC is harsher than HWC [28], and the presence of irradiationinduced defects accelerates corrosion [29]. Critical scientific questions to be addressed include these:

- How does radiolysis potentially affect corrosion behavior?

- How do irradiation-induced defects accelerate corrosion?

- What kind of $\mathrm{SiC}$ microstructure is more resistant to corrosion?

A better understanding of corrosion behavior is essential to assess and optimize the $\mathrm{SiC}$ channel box design and structure. 
An environmental barrier coating (EBC) on the surfaces of channel boxes is a potential solution for mitigating corrosion if $\mathrm{SiC}$ composites undergo unacceptable recession in the coolant. Currently, an EBC for $\mathrm{ATF} \mathrm{SiC} / \mathrm{SiC}$ composite cladding is actively being developed not only as an environmental barrier but also as an additional barrier for hermeticity. Hydrothermal corrosion tests on a Zr-based ATF cladding indicated that a chromium $(\mathrm{Cr})$-based coating is a promising candidate [3]. Preliminary autoclave corrosion tests of $\mathrm{Cr}$-coated $\mathrm{SiC}$ specimens also showed promising corrosion behavior [30]. In addition, a $\mathrm{Cr}$ coating on a $\mathrm{SiC} / \mathrm{SiC}$ composite tube has been demonstrated, as shown in Figure 6 [31]. Development of an EBC coating for channel boxes will have a strong synergy with the development of a coating for the ATF $\mathrm{SiC} / \mathrm{SiC}$ cladding. Modification of the $\mathrm{SiC}$ microstructure by introducing potential corrosionresistant secondary phases has also been pursued. Parish et al. reported the autoclave corrosion behavior of sintered $\mathrm{SiC}$ ceramics with several oxide phases along grain boundaries and grain pockets [32]. It was found that corrosion behavior depends on the type of oxide phases along the grain boundaries and introducing corrosion resistant oxide along the grain boundaries potentially mitigates grain boundary preferential corrosion. A new $\mathrm{SiC}$ material development effort for hydrothermal corrosion mitigation is another potential solution to the corrosion issue, but the technology is immature at this moment.

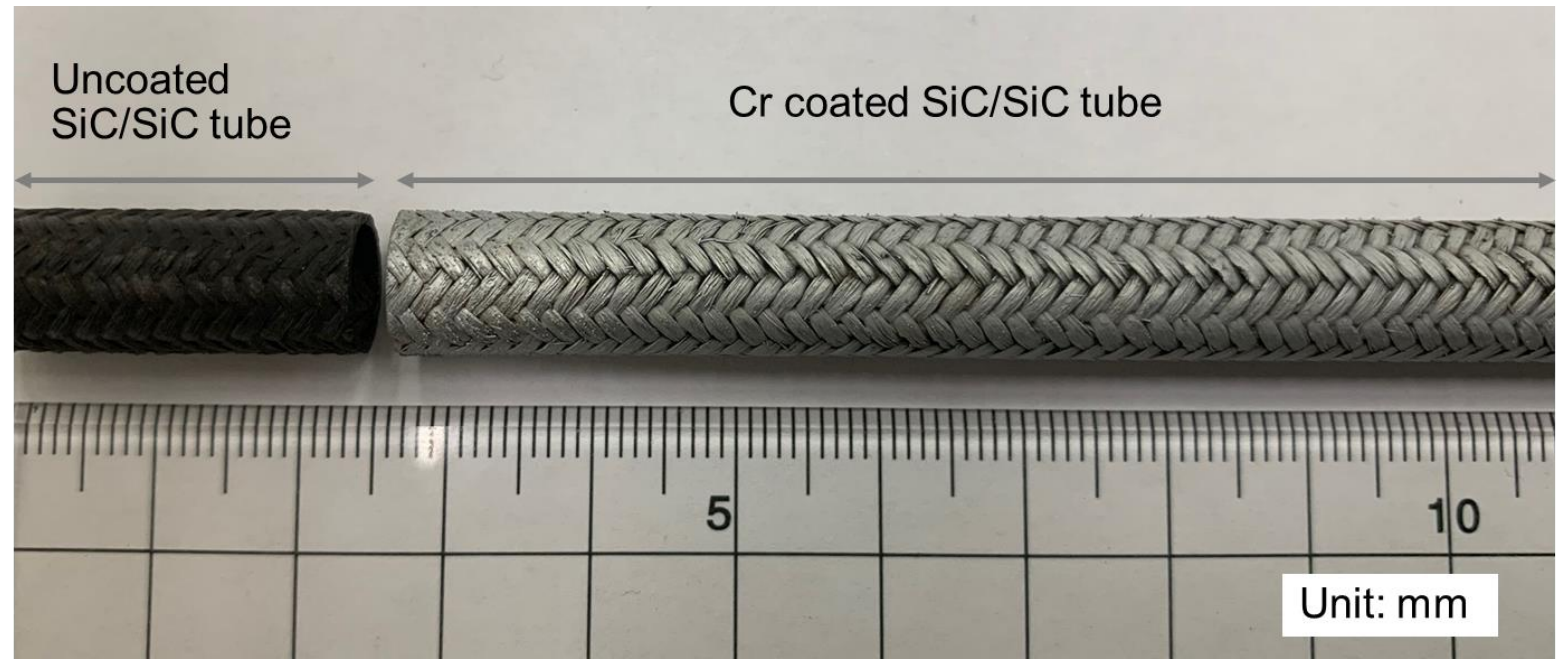

Figure 6. SiC/SiC composite tube coated with chromium by electroplating [31].

\subsection{Irradiation effects}

Effects of neutron irradiation on the dimensional stability (swelling and irradiation creep) and mechanical properties of $\mathrm{SiC} / \mathrm{SiC}$ composites are of critical importance for channel box development. The dose and temperature dependence of swelling needs to be precisely evaluated for better modeling of channel box bowing. Swelling of $\mathrm{SiC} / \mathrm{SiC}$ composite plates has been evaluated for various irradiation conditions [15]. The irradiation temperature-dependent and dose-dependent swelling $(S)$ of CVI SiC/SiC composite plates along the in-plane direction, and of high-purity CVD SiC, is expressed by Eq. (1), based on a recent swelling evaluation using an accurate method of measuring both dimensional change and irradiation temperature [24].

$$
S=S_{S}\left[1-\exp \left(1-\frac{\gamma}{\gamma_{C}}\right)\right]^{2 / 3}
$$




$$
\begin{gathered}
\gamma_{C}=-0.57533+3.3342 \times 10^{-3} T-5.3970 \times 10^{-6} T^{2}+2.9754 \times 10^{-9} T^{3} ; \\
S_{S}=5.8366 \times 10^{-2}-1.0089 \times 10^{-4} T+6.9368 \times 10^{-8} T^{2}-1.8152 \times 10^{-11} T^{3},
\end{gathered}
$$

where $\gamma$ denotes displacement damage in dpa and $T$ denotes irradiation temperature in kelvin $(493 \mathrm{~K}<\mathrm{T}<$ $713 \mathrm{~K})$. Those results were obtained from irradiation studies using HFIR at ORNL. Importantly, Eq. (1) is applicable to CVI SiC/SiC composites used for the channel boxes because part of the specimens in Katoh et al. [24] were machined from the prototypic channel boxes manufactured by Hyper-therm High Temperature Composites. In addition, similar swelling results were obtained from HFIR and the MIT reactor, indicating a limited neutron dose rate effect [12]. The swelling was dose dependent at a certain temperature up to $\sim 1 \mathrm{dpa}$ and approached saturation. This saturation trend has been reported at up to $\sim 100$ dpa (Figure 7) [10]. These results indicate that understanding channel box bowing behavior at a relatively low neutron dose is important. It is expected that dimensions of the channel boxes will be stable beyond the saturation dose $(\sim 1 \mathrm{dpa})$, which is beneficial for an extended service life of the components. Irradiation-induced creep of $\mathrm{SiC}$ is relatively unknown compared with radiation-induced swelling, primarily because of the difficulty of conducting experiments. Although irradiation creep had much less impact on dimensional stability than did swelling [33], recent results of in-pile tensile creep tests of SiC found significant data variation depending on the test conditions [34]. These results point to the need for a high-fidelity irradiation creep model to predict channel box bowing. Knowledge of creep and slow crack growth in $\mathrm{SiC} / \mathrm{SiC}$ composites under neutron irradiation is another subject that has barely been investigated.

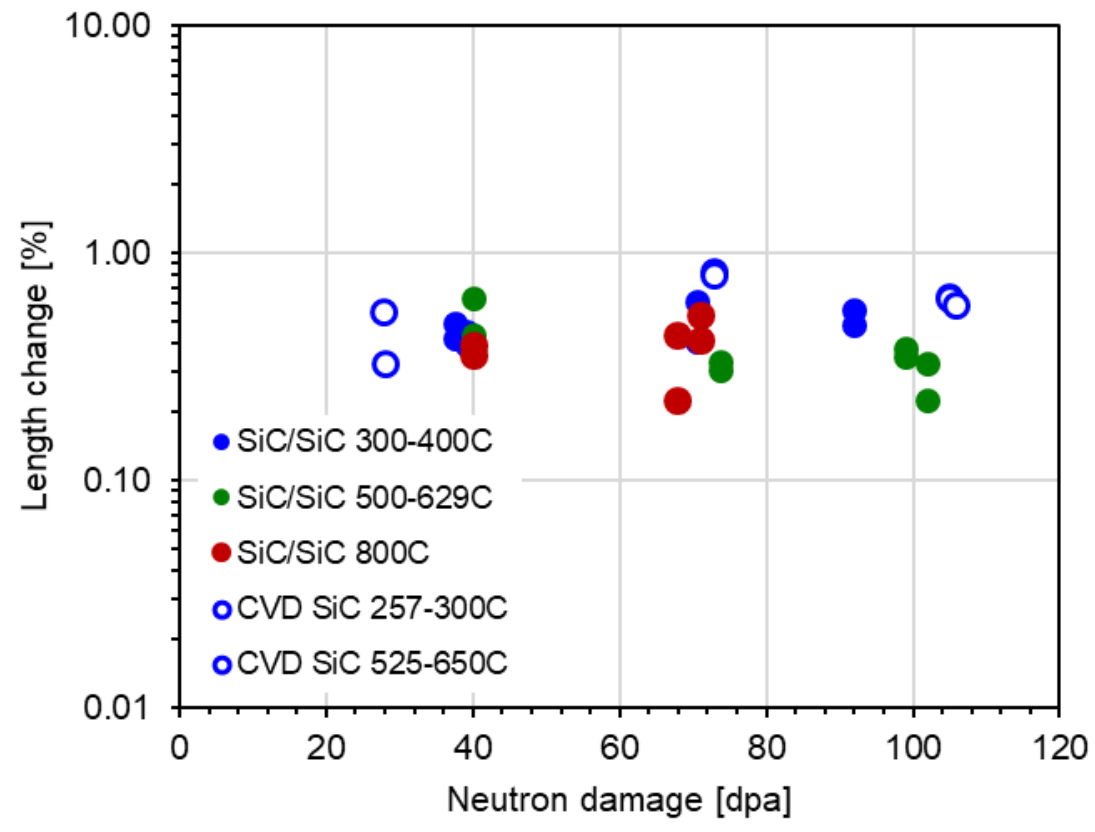

Figure 7. Irradiation dose dependence of swelling of $\mathrm{SiC}[10]$.

Significant degradation of mechanical properties due to neutron irradiation cannot be allowed for BWR channel boxes. Knowledge of the irradiation resistance of $\mathrm{SiC} / \mathrm{SiC}$ composites under LWR-relevant temperature and dose conditions has recently been accumulated for development of $\mathrm{ATF} \mathrm{SiC} / \mathrm{SiC}$ composite cladding. It has been demonstrated that CVI SiC/SiC composites with Hi-Nicalon Type $\mathrm{S}$ and Tyranno SA3 SiC fibers and a pyrolytic carbon interphase retained their mechanical properties following neutron irradiation at $\sim 300^{\circ} \mathrm{C}$ to $12 \mathrm{dpa}$ based on flexural tests at ambient temperature (Figure 8) [22]. A previous study reported notable degradation in the strength of CVI SiC/SiC composites with Hi-Nicalon 
Type $S$ fibers following neutron irradiation at $\sim 300^{\circ} \mathrm{C}$ to $\sim 40 \mathrm{dpa}$. However, it is not clear what radiation dose represents a lifetime neutron dose for strength degradation, or how the irradiation resistance of CVI $\mathrm{SiC} / \mathrm{SiC}$ composites can be improved. These are not feasibility issues but rather an important research topic for the channel box application, because extension of the service life of the $\mathrm{SiC} / \mathrm{SiC}$ composite channel boxes compared with current $\mathrm{Zr}$-based components has potential economic benefits that could be a strong driving force for the development effort. Therefore, the key knowledge gaps are stress-neutron dose-lifetime envelope of the $\mathrm{SiC} / \mathrm{SiC}$ composites and the criteria for acceptable property degradation.

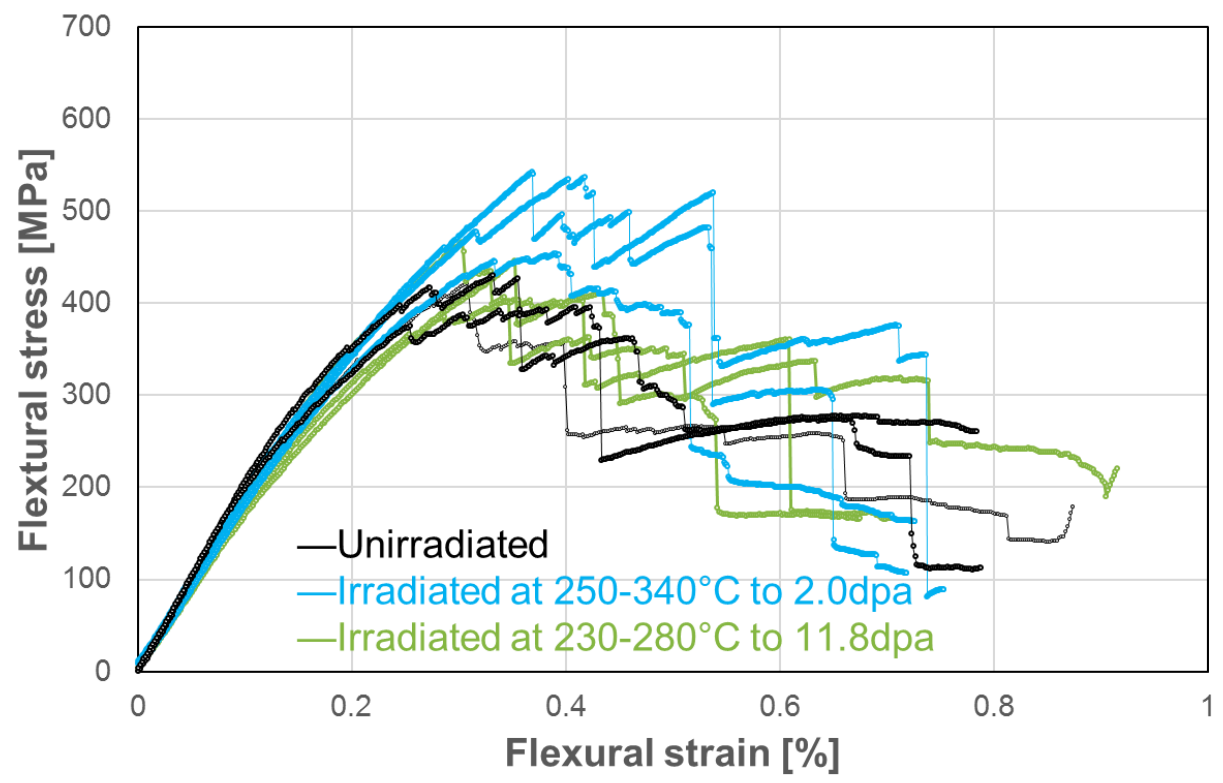

Figure 8. Flexural behavior of $\mathrm{CVI} \mathrm{SiC/SiC} \mathrm{composites} \mathrm{reinforced} \mathrm{with} \mathrm{Hi-Nicalon} \mathrm{Type} \mathrm{S} \mathrm{fibers}$ before and after neutron irradiation [22].

\subsection{Steam oxidation}

The steam oxidation resistance of the channel boxes will be important in the case of a loss-of-coolant accident. Research on the behavior of $\mathrm{SiC}$ materials under high-temperature steam has systematically been conducted as part of studies directed to the development of ATF SiC/SiC composite cladding. This section presents findings regarding the oxidation resistance of CVD SiC, the expected first barrier against steam attack in CVI SiC/SiC composite channel boxes. Oxidation of $\mathrm{SiC}$ in a high-temperature steam environment is expressed by paralinear kinetics: parabolic oxidation forming silica on $\mathrm{SiC}$ and linear volatilization of the silica [2]. The parameters affecting the steam oxidation behavior include temperature, exposure time, steam flow rate, and steam pressure. The parabolic oxidation constants for $\mathrm{SiC}$ in flowing $0.1 \mathrm{MPa}$ steam are reportedly $\sim 3$ orders of magnitude smaller than those for Zircaloy-4 in a temperature range of $1200-1500{ }^{\circ} \mathrm{C}$ [2]. An outstanding low recession rate for CVD SiC compared with Zircaloy-4 was reported [2]. The results shown in [2] are consistent with the results from different steam oxidation studies using high-purity CVD SiC [35], a CVD-coated CVI SiC/SiC composite [36], and sintered $\mathrm{SiC}$ (SE type Hexoloy) [37] under different steam oxidation conditions. Based on the results reported, the steam oxidation resistance of $\mathrm{SiC}$ materials is not a show-stopper but rather a driving force to proceed with development of the $\mathrm{SiC} / \mathrm{SiC}$ composite channel boxes. Although there is general agreement that $\mathrm{SiC}$ oxidizes far less in steam than do $\mathrm{Zr}$ alloys, a critical condition at which $\mathrm{SiC}$ unacceptably undergoes degradation in stream has not been identified. In addition, there is a challenge associated with such hightemperature steam; in extreme conditions beyond $\sim 1600^{\circ} \mathrm{C}$, controlling the environment of the 
experiment is challenging because of significant reaction of the high-temperature furnace during testing [2]. In the case of SiC-based channel boxes with an EBC, the steam oxidation behavior of the coated system needs to be assessed. Moreover, stress corrosion cracking of $\mathrm{SiC} / \mathrm{SiC}$ composites was missing in the previous studies. Therefore, there is still a knowledge gap regarding steam corrosion of $\mathrm{SiC}$ that prevents better understanding of $\mathrm{SiC}$ behavior under off-normal conditions.

\subsection{Accident analysis}

Although SiC materials have been proven to be more resistant to steam oxidation than Zr-based alloys, further analysis of the responses to accident conditions is required. This task discusses three key elements of the accident analysis: thermal shock resistance, stored energy release, and modeling of accident behavior.

In the event of a loss-of-coolant accident, the high-temperature fuel assemblies, including the channel boxes, are expected to experience rapid cooling during core reflooding. In this scenario, the channel boxes must be resistant to thermal shock, meaning they retain their structure without catastrophic failure. In this case, microcracking within the SiC material may be acceptable. Yueh et al. conducted quenching tests of a prototype CVI SiC/SiC channel box [17]. As reported in [17], the test specimen retained its structure after rapid cooling from 800 to $135^{\circ} \mathrm{C}$. Currently, only limited data are available for the thermal shock resistance of $\mathrm{SiC} / \mathrm{SiC}$ channel boxes. Thermal shock damage to $\mathrm{SiC}$ tubular specimens was also investigated. $\mathrm{SiC} / \mathrm{SiC}$ composites and monolithic $\mathrm{SiC}$ were heated to $1200-2000^{\circ} \mathrm{C}$ and then waterquenched $[36,38,39]$. These results showed retention of the specimen shape after the quench tests. Importantly, Kim et al. reported that the quench tests resulted in less than $13 \%$ degradation of the ultimate hoop strength of multi-layered SiC composite tubes [38].

Stored energy release during rapid annealing of irradiated $\mathrm{SiC} / \mathrm{SiC}$ channel boxes must be considered in the accident analysis. The energy released during the recovery of irradiation-induced Frenkel pairs is called the "Wigner energy." The potential danger of stored energy release during reactor operation was discovered early in the operation of the air-cooled graphite reactors at Windscale in the United Kingdom. To prevent the build-up of excessive amounts of stored energy, the reactors were routinely thermally annealed to reduce the extent of the $200^{\circ} \mathrm{C}$ release peak. However, the 1957 Windscale Reactor 1 fire was initiated by an anomalous stored energy release during one of these scheduled anneals. Although stored energy release is not unique to graphite, in practical terms, no other nuclear ceramic has demonstrated an issue with Wigner energy. Given the relatively high energy for defect recombination and relevance to nuclear energy, the Wigner energy potential for SiC was investigated by Primak in 1956 [40]. Although this work concluded that the stored energy release of $\mathrm{SiC}$ was not significant, the neutron dose was only $\sim 0.04$ dpa.

Recently, Snead et al. experimentally investigated stored energy release in a CVD SiC monolith neutron irradiated at $\sim 60^{\circ} \mathrm{C}$ to $0.05-20 \mathrm{dpa}$; they used differential scanning calorimetry at up to $700^{\circ} \mathrm{C}$ [41]. There was a clear correlation between stored energy release and recovery of swelling, and the maximum stored energy release measured was at the $7.7 \%$ swelling point, yielding $1390 \mathrm{~J} / \mathrm{g}$ (Figure 13). This significant amount of energy release indicates that stored energy is especially important for SiC channel boxes in the event of an accident in which a high temperature ramping rate causes stored energy release in a short period of time. Since the irradiation temperature in the Snead et al. study is not relevant to LWR applications, and radiation temperature largely affects the defect structure and stored energy, further experimental investigation of stored energy release is necessary to assess the accident behavior of $\mathrm{SiC}$ channel boxes.

During stored energy release, the dimensions and the thermal conductivity of SiC continuously change as a result of the recovery of radiation defects. The kinetics of these property changes during annealing will be one of the critical input parameters for modeling accident scenarios. It is well known that recovery of 
radiation defects starts beyond the irradiation temperature [42]. Currently, data relating the kinetics of defect recovery in $\mathrm{SiC}$ are limited [43], and experiments specifically simulating accident conditions are required. Finally, simulations of the responses of channel boxes to accident conditions are currently lacking, although simulation is important. An accident scenario can involve a complex situation including coolant pressure drop and channel box dryout, which is a challenge for accident analysis. Simulations of the time-dependent temperature increase and temperature distribution within the components need to consider stored energy release. Simulations will provide the appropriate conditions for the thermal shock tests that are needed. Potential eutectic formation among the channel boxes and other core components will be another challenge under a severe accident condition. In addition, the modeling approach may be useful for refining channel box structure and design.

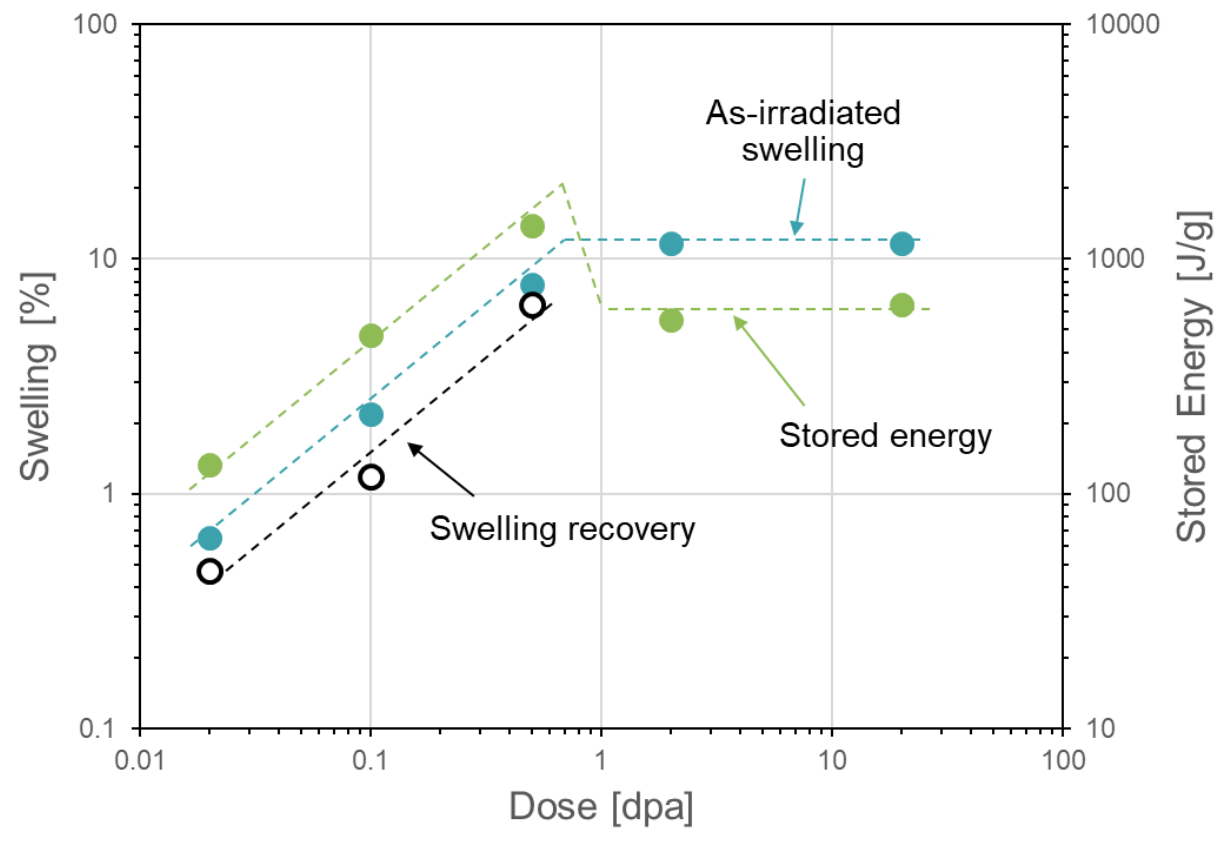

Figure 9. Neutron dose-dependent swelling and stored energy release of CVD SiC [41].

\subsection{Summary of key feasibility issues}

Based on the knowledge gap analysis discussed, we identified key feasibility issues in the development of $\mathrm{SiC} / \mathrm{SiC}$ composite channel boxes: irradiation effects, hydrothermal corrosion, accident behavior, and design and manufacturing. Important irradiation effects to be investigated include channel box bowing and high-dose neutron irradiation effects on the mechanical properties. Channel box bowing is a key feasibility issue, and high-dose irradiation is a lifetime limiting factor. Understanding of hydrothermal corrosion is immature mainly because of a lack of in-pile hydrothermal corrosion experiments. In addition, corrosion mitigation strategies are required in case the corrosion rate is not acceptable. Note that this is a common issue in cladding and channel box development. In addition, the accident resistance of channel boxes must be demonstrated. Stored energy release during rapid annealing of the components is a key factor for accident analysis of both channel boxes and cladding. Thermo-mechanical analysis of channel boxes under accident conditions, and demonstration of their mechanical integrity under accident conditions by experiments such as quenching tests, are essential. Furthermore, a full-size SiC-based 
channel box needs to be demonstrated. The following sections provide a systematic technology evaluation program to fill these knowledge gaps and proceed with channel box development.

\section{SYSTEMATIC TECHNOLOGY EVALUATION PROGRAM}

The objectives of the systematic technology evaluation program for SiC-based channel box development are to address key feasibility issues found in the knowledge gap analysis and to contribute to advancing the technology readiness level. The technology evaluations include understanding the key in-pile behavior of channel boxes, identifying potential mitigation strategies for the issues if necessary, and improving the performance of channel boxes based on the knowledge obtained. The technology evaluation program also identifies common and unique issues among LWR cladding and channel box development which affect the technology evaluation strategies. The proposed work on four key feasibility issues is discussed in this section.

\subsection{Irradiation effects}

There are two tasks in the irradiation effects area: channel box bowing and lifetime assessment. A summary of this task is shown in Table 1 . To address the channel box bowing issue, a combination of experiment and modeling is an essential approach to understand the behavior and identify potential mitigation strategies. Preliminary modeling of channel box bowing has been conducted, considering temperature and neutron dose-dependent SiC swelling [19]. Although the modeling work suggested significant bowing depending on the channel box constraints, this needs to be demonstrated by experiment. The ORNL program has designed a channel box bowing experiment at HFIR with a BWRrepresentative neutron flux gradient within a miniature $\mathrm{CVI} \mathrm{SiC/SiC}$ composite channel box at $\sim 60^{\circ} \mathrm{C}$ [20]. Since the irradiation temperature is not representative for BWR environments owing to limitations of the reactor experiment, further demonstration of channel box bowing at $\sim 300^{\circ} \mathrm{C}$ will be required. The initial irradiation experiment will demonstrate the presence of bowing and address how to design the reactor experiment and accurately evaluate channel deformation. In addition, the experimental results will be used to validate or refine modeling of the bowing. The verified model will be used for full core computational analysis to map out deformation and stress within each channel box. If the extent of channel box bowing is not acceptable, potential mitigation strategies will be considered. The capability to model channel box bowing will be useful for identifying solutions by parametric studies of channel box bowing with different fuel assembly structures and modified composite materials. Bowing is also a concern for ATF SiC/SiC composite cladding, as a modeling study by Singh et al. pointed out [7]. Since bowing of the channel box and of the cladding has the same cause (primarily the radiation swelling gradient within the components), establishing a modeling capability will be beneficial for both development efforts. 
Table 1. Task structure, objectives, and outline in evaluations of irradiation effects.

\begin{tabular}{lll}
\hline Task name & Description & Status \\
\hline Channel box bowing & $\begin{array}{l}\text { (1) Experimental evaluation of channel box } \\
\text { bowing }\end{array}$ & $\begin{array}{l}\text { (1) Preliminary modeling conducted } \\
\text { [19] }\end{array}$ \\
& (2) Validation of channel box bowing model & (2) Reactor experiment designed [20] \\
& (3) full reactor core analysis & (3) Not initiated \\
\hline Lifetime assessment & $\begin{array}{l}\text { (1) Stress-neutron dose-lifetime envelope of } \\
\text { SiC/SiC composites }\end{array}$ & (1-2) High-dose neutron irradiation \\
& $\begin{array}{l}\text { (2) Criteria for acceptable property } \\
\text { degradation and failure }\end{array}$ & (3) Preliminary results available [34] \\
& and new radiation experiment planned \\
& (3) Development of irradiation creep model & \\
\hline
\end{tabular}

Lifetime assessment of $\mathrm{SiC} / \mathrm{SiC}$ composites based on high-dose neutron irradiation also needs to be addressed. Establishment of a stress-neutron dose-lifetime envelope for $\mathrm{SiC} / \mathrm{SiC}$ composites is one of the key aspects of this study. The ORNL program is currently conducting high-dose neutron irradiation of $\mathrm{CVI} \mathrm{SiC/SiC} \mathrm{composites} \mathrm{with} \mathrm{different} \mathrm{fiber/interface} \mathrm{systems} \mathrm{to} \mathrm{optimize} \mathrm{the} \mathrm{composite} \mathrm{structure.} \mathrm{Some}$ of the results are available in Koyanagi and Katoh 2017 [22]. The results of a previous study [10] indicated that microstructural degradation of the fiber/matrix interface played an important role in the mechanical properties of high-dose irradiated $\mathrm{SiC} / \mathrm{SiC}$ composites. The lifetime of composite materials requires criteria for acceptable mechanical degradation and definition of failure. Since matrix cracking of the $\mathrm{SiC} / \mathrm{SiC}$ composite exposes the fiber and carbon interphase and consequently accelerates hydrothermal and steam corrosion, the nature of microcracks under different loading conditions and the probability of such cracking will determine the failure conditions of the composites. Because of the knowledge gaps for radiation-induced dimensional change of $\mathrm{SiC} / \mathrm{SiC}$ composites under applied stresses, irradiation creep and slow crack growth under reactor environments also need to be investigated as part of the material life assessment. This study aims to advance the current irradiation creep modeling of SiC [44] to develop a more accurate model capturing anisotropic radiation defect buildup and crack growth.

\subsection{Hydrothermal corrosion}

Hydrothermal corrosion of $\mathrm{SiC}$ materials has been actively investigated for ATF SiC/SiC cladding. However, the in-pile corrosion behavior is still not well understood because of a lack of opportunity for in-pile testing. The corrosion study of the channel boxes has a focus specifically on BWR HWC and NWC environments. Table 2 shows the task structure of the hydrothermal corrosion research. Autoclave testing is still useful for testing various grades of $\mathrm{SiC}$ materials to identify the most corrosion resistant microstructure, understand the effects of different water chemistries on corrosion of SiC-based materials on a thermodynamic basis, and develop a fundamental corrosion database. Promising SiC materials selected based on the autoclave tests need to be tested in-pile with BWR HWC and NWC. Only preliminary in-pile corrosion data with BWR-relevant chemistry are available in Yueh 2017 [12], and very limited analysis has been conducted. The in-pile corrosion tests will clarify how radiolysis and the presence of irradiation-induced defects affect corrosion behavior. Previous studies $[12,28]$ suggest the possibility of an unacceptable rate of corrosion of SiC under BWR NWC. Although this suggestion is not conclusive, the current understanding is that corrosion mitigation strategies must be provided under NWC for the realization of $\mathrm{SiC}$ channel boxes. A potential solution is an $\mathrm{EBC}$ on the channel box surfaces, the 
same solution proposed for $\mathrm{ATF} \mathrm{SiC} / \mathrm{SiC}$ composite cladding [31]. It is necessary to demonstrate a corrosion-resistant coating. The preliminary study will use autoclave testing for material screening and a proof-of-concept study. In addition, a scalable coating process needs to be demonstrated. A chromiumbased material recognized as one of the promising candidates for coating has been demonstrated for ATFcoated $\mathrm{Zr}$ cladding [3]. This task will continue to leverage achievements from the development of ATF $\mathrm{SiC} / \mathrm{SiC}$ cladding. Modification of $\mathrm{SiC}$ by introducing a secondary phase or doping is another option for corrosion mitigation, which has not been initiated yet.

Table 2. Task structure, objectives. and outline in hydrothermal corrosion evaluations.

\begin{tabular}{lll}
\hline Task name & Description & Status \\
\hline Corrosion mitigation & $\begin{array}{l}\text { (1) Demonstration of corrosion } \\
\text { mitigation coating on SiC/SiC } \\
\text { composites } \\
\text { (2) Development of scalable coating } \\
\text { process }\end{array}$ & $\begin{array}{l}\text { (1-2) Work in progress [31] } \\
\text { (3) Development of corrosion-resistant }\end{array}$ \\
& composite & \\
\hline Autoclave corrosion testing & $\begin{array}{l}\text { (1) Testing of various grades of SiC to } \\
\text { identify a corrosion-resistant material }\end{array}$ & (1-3) Work in progress [30] \\
& $\begin{array}{l}\text { (2) Testing under different BWR- } \\
\text { relevant chemistries to identify } \\
\text { corrosion process }\end{array}$ & \\
& $\begin{array}{l}\text { (3) Development of a basic } \\
\text { thermodynamic basis for the process }\end{array}$ & \\
\hline In-pile corrosion testing with & $\begin{array}{l}\text { (1) In-pile corrosion testing with BWR- } \\
\text { relevant chemistry }\end{array}$ & (1-3) Only preliminary results \\
BWR chemistry & (2) Evaluation of corroded specimens & \\
& (3) Analysis of the effects of radiolysis & \\
and radiation defects on corrosion & \\
\hline
\end{tabular}

\subsection{Accident behavior}

The task structure for channel box accident analysis is shown in Table 3. A limited accident analysis for BWR SiC channel boxes has been conducted. To ensure that the channel boxes retain their geometry in a loss-of-coolant accident, the thermal shock resistance of the channel boxes needs to be experimentally demonstrated. Understanding thermal shock damage in $\mathrm{SiC} / \mathrm{SiC}$ composites will require (1) evaluation of baseline thermal and mechanical properties of $\mathrm{SiC} / \mathrm{SiC}$ composites, (2) quench tests of the channel boxes under controlled environments, and (3) evaluation of the residual strength of the test specimens after the quench tests. Analysis of micro and macro cracks introduced by thermal shock will provide insight on thermal shock degradation processes. Such a systematic study has hardly been conducted even for ATF $\mathrm{SiC} / \mathrm{SiC}$ composite cladding. The critical thermal shock conditions resulting in a loss of material strength need to be identified.

Stored energy is a key topic for both $\mathrm{SiC}$-based channel boxes and fuel cladding. Stored energy release of $\mathrm{SiC}$ must be evaluated in detail using $\mathrm{SiC}$ materials neutron-irradiated under LWR-relevant temperature 
conditions, as data are available only for relatively low irradiation temperatures [40,41]. Experimental measurements of the stored energy at different heating rates will be critical data used for accident analysis of SiC-based core components. Predictions of time- and temperature-dependent stored energy release under different irradiation temperatures and neutron doses must be delivered from analysis of the experimental results. Changes in physical properties associated with recovery of radiation defects in $\mathrm{SiC}$ at elevated temperatures will also be necessary for accident analysis.

Steam oxidation is still an important task for accident analysis. Controlling the steam environment under very high temperatures has been recognized a challenge to be overcome for better understanding of corrosion behavior and identification of material degradation processes. Steam oxidation of channel boxes with EBCs or of any SiC materials newly developed for hydrothermal corrosion resistance will be investigated to ensure steam oxidation resistance. Stress corrosion cracking research is currently lacking and needs to be addressed. In short, the steam oxidation studies need to identify boundary conditions under which $\mathrm{SiC}$ materials degrade unacceptably.

In addition to the experiments, simulation of temperature and strain distributions within the channel boxes during accident conditions will be required. The simulations must consider not only stored energy release during a loss-of-coolant accident but also other phenomena, including chemical compatibility among the $\mathrm{SiC}$ materials and other metallic components surrounding the channel boxes. Once a solid modeling capability is developed, this computational tool will be useful for optimization of the channel box structure and design. 
Table 3. Task structure, objectives, and outline in accident resistance.

\begin{tabular}{|c|c|c|}
\hline Task name & Description & Status \\
\hline \multirow[t]{3}{*}{ Thermal shock resistance } & $\begin{array}{l}\text { (1) Evaluation of baseline thermal and } \\
\text { mechanical properties of } \mathrm{SiC} \text { channel } \\
\text { boxes }\end{array}$ & \multirow[t]{3}{*}{$\begin{array}{l}\text { (1-3) Only preliminary results } \\
\text { reported }[12,36,38,39]\end{array}$} \\
\hline & (2) Quench testing of channel boxes & \\
\hline & $\begin{array}{l}\text { (3) Evaluation of the residual strength } \\
\text { after the quench tests }\end{array}$ & \\
\hline \multirow[t]{3}{*}{ Stored energy release } & $\begin{array}{l}\text { (1) Measurements of stored energy } \\
\text { release of SiC irradiated at LWR- } \\
\text { relevant temperatures }\end{array}$ & \multirow{3}{*}{$\begin{array}{l}(1-2) \text { Only preliminary results } \\
\text { reported [41] } \\
\text { (3) Limited data available [43] }\end{array}$} \\
\hline & $\begin{array}{l}\text { (2) Analysis of time-dependent stored } \\
\text { energy release at different heating rates }\end{array}$ & \\
\hline & $\begin{array}{l}\text { (3) Evaluation of kinetics of recovery of } \\
\text { physical properties associated with } \\
\text { radiation defect annihilation at elevated } \\
\text { temperatures }\end{array}$ & \\
\hline \multirow[t]{3}{*}{ Steam oxidation } & $\begin{array}{l}\text { (1) Steam oxidation under extreme } \\
\text { conditions }\end{array}$ & \multirow{3}{*}{$\begin{array}{l}\text { (1) Issues identified for testing at } \\
\text { very high temperatures [2] } \\
\text { (2-3) Not initiated }\end{array}$} \\
\hline & $\begin{array}{l}\text { (2) Steam oxidation of } \mathrm{SiC} \text { with } \mathrm{EBC} \text { or } \\
\text { newly developed materials }\end{array}$ & \\
\hline & (3) Stress corrosion cracking in steam & \\
\hline \multirow[t]{3}{*}{ Modeling of accident behavior } & $\begin{array}{l}\text { (1) Modeling of temperature and strain } \\
\text { distributions within } \mathrm{SiC} \text { channel boxes } \\
\text { under accident conditions }\end{array}$ & \multirow[t]{3}{*}{ (1-3) Not initiated } \\
\hline & $\begin{array}{l}\text { (2) Sensitivity analysis of stored energy } \\
\text { release }\end{array}$ & \\
\hline & $\begin{array}{l}\text { (3) Optimization of channel box design } \\
\text { using modeling tool }\end{array}$ & \\
\hline
\end{tabular}

\subsection{Design and manufacture}

Key tasks for design and manufacture of the channel boxes are listed in Table 4. Demonstration of a fullscale channel box is an obvious task to be accomplished by industry, as only a section of a channel box has been demonstrated at this time [12]. General Atomics is preparing miniature $\mathrm{SiC} / \mathrm{SiC}$ composite channel boxes for the neutron irradiation experiment in HFIR to evaluate channel box bowing [20]. A quality assessment of the channel box (e.g., processing defects, structure uniformity) will be conducted during the evaluation process of the irradiation study; it will provide important feedback for processing. In addition to improvement of the processing, optimization of the composite microstructure will be pursued; the desired fiber architecture, constituent materials and their fractions, porosity, and surface roughness will be proposed based on evaluation of the irradiation effects, hydrothermal corrosion, and accident behavior. The mechanistic basis of these three environmental effects of the composite properties 
will guide the development of a composite microstructure with better properties. Note that the necessary trade-offs among the various composite properties achieved by tailoring of the composite microstructures will be determined through the material optimization process. In addition to the composite design, the design of the channel boxes needs to be refined. It is expected that minor modifications of the channel box design, including channel dimensions, will be allowed to maximize the in-pile performance and structural reliability of the component. Such modifications would ideally be minor to allow for SiC channel boxes to be a drop-in replacement for current BWRs. The established fuel performance model will be a useful tool for this purpose. Finally, continuing efforts toward material qualification and a test method standard for the channel box application will be necessary for licensing.

Table 4. Task structure, objectives, and outline in design and manufacture.

\begin{tabular}{lll}
\hline Task name & Description & Status \\
\hline $\begin{array}{l}\text { Composite design and } \\
\text { manufacture }\end{array}$ & $\begin{array}{l}\text { (1) Full-scale channel box } \\
\text { (2) Material modification and } \\
\text { optimization }\end{array}$ & $\begin{array}{l}\text { (1) A section of the component } \\
\text { fabricated [12] } \\
\text { (2) Not initiated }\end{array}$ \\
\hline Design qualification & $\begin{array}{l}\text { (1) Channel box design refinement } \\
\text { (2) Material code and standard for } \\
\text { licensing }\end{array}$ & $\begin{array}{l}\text { (1) Not initiated } \\
\text { (2) Only general specification } \\
\text { available [25] }\end{array}$ \\
\hline
\end{tabular}

\section{ACKNOWLEDGMENTS}

The research is sponsored by the Advanced Fuels Campaign of the Nuclear Technology R\&D program, Office of Nuclear Energy, US Department of Energy, under contract DE-AC05-00OR22725 with UTBattelle LLC. The authors wish to thank Andrew Nelson, Christian Petrie, Peter Mouche, Nicholas Brown, and Yoonjo Lee at ORNL for valuable comments on this report. 
6. REFERENCES

[1] S.J. Zinkle, K.A. Terrani, J.C. Gehin, L.J. Ott, L.L. Snead, Accident tolerant fuels for LWRs: A perspective, J. Nucl. Mater. 448 (2014) 374-379. doi:10.1016/j.jnucmat.2013.12.005.

[2] K.A. Terrani, B.A. Pint, C.M. Parish, C.M. Silva, L.L. Snead, Y. Katoh, Silicon carbide oxidation in steam up to $2 \mathrm{MPa}$, J. Am. Ceram. Soc. 97 (2014) 2331-2352. doi:10.1111/jace.13094.

[3] K.A. Terrani, Accident tolerant fuel cladding development: Promise, status, and challenges, J. Nucl. Mater. 501 (2018) 13-30. doi:10.1016/j.jnucmat.2017.12.043.

[4] Y. Katoh, L.L. Snead, I. Szlufarska, W.J. Weber, Radiation effects in SiC for nuclear structural applications, Curr. Opin. Solid State Mater. Sci. 16 (2012) 143-152. doi:10.1016/j.cossms.2012.03.005.

[5] C.P. Deck, G.M. Jacobsen, J. Sheeder, O. Gutierrez, J. Zhang, J. Stone, H.E. Khalifa, C.A. Back, Characterization of SiC-SiC composites for accident tolerant fuel cladding, J. Nucl. Mater. 466 (2015) 1-15. doi:10.1016/j.jnucmat.2015.08.020.

[6] M. Ben-Belgacem, V. Richet, K.A. Terrani, Y. Katoh, L.L. Snead, Thermo-mechanical analysis of LWR SiC/SiC composite cladding, J. Nucl. Mater. 447 (2014) 125-142. doi:10.1016/j.jnucmat.2014.01.006.

[7] G. Singh, R. Sweet, N.R. Brown, B.D. Wirth, Y. Katoh, K. Terrani, Parametric Evaluation of SiC/SiC Composite Cladding with UO2Fuel for LWR Applications: Fuel Rod Interactions and Impact of Nonuniform Power Profile in Fuel Rod, J. Nucl. Mater. 499 (2018) 155-167. doi:10.1016/j.jnucmat.2017.10.059.

[8] Y. Deng, K. Shirvan, Y. Wu, G. Su, Probabilistic view of SiC/SiC composite cladding failure based on full core thermo-mechanical response, J. Nucl. Mater. 507 (2018) 24-37. doi:10.1016/j.jnucmat.2018.04.023.

[9] T. Koyanagi, Y. Katoh, G. Jacobsen, C. Deck, Handbook of LWR SiC/SiC Cladding PropertiesRevision 1, 2018. https://info.ornl.gov/sites/publications/Files/Pub113355.pdf.

[10] T. Koyanagi, T. Nozawa, Y. Katoh, L.L. Snead, Mechanical property degradation of high crystalline $\mathrm{SiC}$ fiber-reinforced $\mathrm{SiC}$ matrix composite neutron irradiated to 100 displacements per atom, J. Eur. Ceram. Soc. 38 (2018) 1087-1094. doi:10.1016/J.JEURCERAMSOC.2017.12.026.

[11] F. Garzarolli, R. Adamson, P. Rudling, A. Strasser, BWR Fuel Channel Distortion, 2011. www.antinternational.com.

[12] Yueh, Ken, SiC Composite for Fuel Structure Applications, (2017). https://www.osti.gov/servlets/purl/1415452.

[13] T. Koyanagi, Y. Katoh, T. Nozawa, L.L. Snead, S. Kondo, C.H. Henager, M. Ferraris, T. Hinoki, Q. Huang, Recent progress in the development of SiC composites for nuclear fusion applications, J. Nucl. Mater. 511 (2018) 544-555. doi:10.1016/j.jnucmat.2018.06.017.

[14] C. Sauder, Ceramic Matrix Composites: Nuclear Applications, in: Ceram. Matrix Compos. Mater. Model. Technol., 2014: pp. 609-646. doi:10.1002/9781118832998.ch22.

[15] Y. Katoh, K. Ozawa, C. Shih, T. Nozawa, R.J. Shinavski, A. Hasegawa, L.L. Snead, Continuous $\mathrm{SiC}$ fiber, CVI SiC matrix composites for nuclear applications: Properties and irradiation effects, J. Nucl. Mater. 448 (2014) 448-476. doi:10.1016/j.jnucmat.2013.06.040.

[16] T. Koyanagi, K. Ozawa, T. Hinoki, K. Shimoda, Y. Katoh, Effects of neutron irradiation on mechanical properties of silicon carbide composites fabricated by nano-infiltration and transient 
eutectic-phase process, J. Nucl. Mater. 448 (2014) 478-486. doi:10.1016/j.jnucmat.2013.10.005.

[17] K. Yueh, K.A. Terrani, Silicon carbide composite for light water reactor fuel assembly applications, J. Nucl. Mater. 448 (2014) 380-388. doi:10.1016/j.jnucmat.2013.12.004.

[18] Y. Katoh, K.A. Terrani, Systematic Technology Evaluation Program for SiC/SiC Composite-based Accident-Tolerant LWR Fuel Cladding and Core Structures: Revision 2015, 2015. http://www.osti.gov/scitech/.

[19] G. Singh, J. Gorton, D. Schappel, N.R. Brown, Y. Katoh, B.D. Wirth, K.A. Terrani, Deformation analysis of SiC-SiC channel box for BWR applications, J. Nucl. Mater. (2019). doi:10.1016/j.jnucmat.2018.10.045.

[20] C.M. Petrie, K.R. Smith, J.R. Burns, A.G. Le Coq, Y. Katoh, C.P. Deck, Irradiation Testing of a $\mathrm{SiC} / \mathrm{SiC}$ Channel Box in the High Flux Isotope Reactor, 2018. https://info.ornl.gov/sites/publications/Files/Pub115092.pdf.

[21] G. Singh, S. Gonczy, C. Deck, E. Lara-Curzio, Y. Katoh, Interlaboratory round robin study on axial tensile properties of SiC-SiC CMC tubular test specimens, Int. J. Appl. Ceram. Technol. (2018). doi:10.1111/ijac.13010.

[22] T. Koyanagi, Y. Katoh, Mechanical properties of SiC composites neutron irradiated under light water reactor relevant temperature and dose conditions, J. Nucl. Mater. 494 (2017) 46-54. doi:10.1016/j.jnucmat.2017.07.007.

[23] P. Ferroni, Steady state thermal hydraulic analysis of hydride fueled BWRs, Massachusetts Institute of Technology, 2006. https://dspace.mit.edu/handle/1721.1/41263.

[24] Y. Katoh, T. Koyanagi, J.L. McDuffee, L.L. Snead, K. Yueh, Dimensional stability and anisotropy of SiC and SiC-based composites in transition swelling regime, J. Nucl. Mater. 499 (2018) 471479. doi:10.1016/j.jnucmat.2017.12.009.

[25] G. Articles, C.T. Method, G. Shapes, A. Spe-, C1793-15: Standard Guide for Development of Specifications for Fiber Reinforced Silicon Carbide-Silicon Carbide Composite Structures for Nuclear Application, ASTM Int. i (2016) 1-14. doi:10.1520/C1793-15.

[26] C.C. Lin, F.R. Smith, R.L. Cowan, Effects of hydrogen water chemistry on radiation field buildup in BWRs, Nucl. Eng. Des. 166 (1996) 31-36. doi:10.1016/0029-5493(96)01196-X.

[27] C.C. Lin, A review of corrosion product transport and radiation field buildup in boiling water reactors, Prog. Nucl. Energy. 51 (2009) 207-224. doi:10.1016/j.pnucene.2008.05.005.

[28] K.A. Terrani, Y. Yang, Y.J. Kim, R. Rebak, H.M. Meyer, T.J. Gerczak, Hydrothermal corrosion of SiC in LWR coolant environments in the absence of irradiation, J. Nucl. Mater. 465 (2015) 488-498. doi:10.1016/j.jnucmat.2015.06.019.

[29] S. Kondo, S. Mouri, Y. Hyodo, T. Hinoki, F. Kano, Role of irradiation-induced defects on SiC dissolution in hot water, Corros. Sci. 112 (2016) 402-407. doi:10.1016/j.corsci.2016.08.007.

[30] S.S. Raiman, P. Doyle, C. Ang, Y. Katoh, K.A. Terrani, Hydrothermal Corrosion of Coatings on Silicon Carbide in Boiling Water Reactor Conditions, CORROSION. 75 (2019) 217-223. doi:10.5006/2997.

[31] C. Ang, C. Kemery, Y. Katoh, Electroplating chromium on CVD SiC and SiCf-SiC advanced cladding via PyC compatibility coating, J. Nucl. Mater. 503 (2018) 245-249. doi:10.1016/J.JNUCMAT.2018.03.009.

[32] C.M. Parish, K.A. Terrani, Y.-J. Kim, T. Koyanagi, Y. Katoh, Microstructure and hydrothermal corrosion behavior of NITE-SiC with various sintering additives in LWR coolant environments, J. 
Eur. Ceram. Soc. 37 (2017). doi:10.1016/j.jeurceramsoc.2016.11.033.

[33] T. Koyanagi, Y. Katoh, K. Ozawa, K. Shimoda, T. Hinoki, L.L. Snead, Neutron-irradiation creep of silicon carbide materials beyond the initial transient, J. Nucl. Mater. 478 (2016) 97-111. doi:10.1016/j.jnucmat.2016.06.006.

[34] K.A. Terrani, T.M. Karlsen, Y. Yamamoto, Fuel Cycle Research \&amp; Development Advanced Fuels Campaign Input Correlations for Irradiation Creep of FeCrAl and SiC Based on In-Pile Halden Test Results, ORNL/TM-20 (2016). https://info.ornl.gov/sites/publications/files/Pub62748.pdf.

[35] D.J. Park, Y. Il Jung, H.G. Kim, J.Y. Park, Y.H. Koo, Oxidation behavior of silicon carbide at $1200^{\circ} \mathrm{C}$ in both air and water-vapor-rich environments, Corros. Sci. 88 (2014) 416-422. doi:10.1016/j.corsci.2014.07.052.

[36] V. Angelici Avincola, M. Grosse, U. Stegmaier, M. Steinbrueck, H.J. Seifert, Oxidation at high temperatures in steam atmosphere and quench of silicon carbide composites for nuclear application, Nucl. Eng. Des. 295 (2015) 468-478. doi:10.1016/j.nucengdes.2015.10.002.

[37] Y. Lee, T.J. McKrell, A. Montecot, M. Pantano, Y. Song, M.S. Kazimi, Oxidation behavior of sintered tubular silicon carbide in pure steam I: Experiments, Ceram. Int. 42 (2016) 1916-1925. doi:10.1016/J.CERAMINT.2015.09.161.

[38] D. Kim, D. Lee, S. Lee, K. Park, H.-G. Lee, J.Y. Park, W.-J. Kim, Thermal shock resistance and hoop strength of triplex silicon carbide composite tubes, Int. J. Appl. Ceram. Technol. 14 (2017) 1069-1076. doi:10.1111/ijac.12753.

[39] Y. Lee, T.J. McKrell, M.S. Kazimi, Thermal shock fracture of hot silicon carbide immersed in water, J. Nucl. Mater. (2015). doi:10.1016/j.jnucmat.2015.09.020.

[40] W. Primak, L.H. Fuchs, P.P. Day, Radiation damage in diamond and silicon carbide, Phys. Rev. 103 (1956) 1184-1192. doi:10.1103/PhysRev.103.1184.

[41] L.L. Snead, Y. Katoh, T. Koyanagi, K. Terrani, Stored energy release in neutron irradiated silicon carbide, J. Nucl. Mater. 514 (2019) 181-188. doi:10.1016/j.jnucmat.2018.12.005.

[42] A.A. Campbell, W.D. Porter, Y. Katoh, L.L. Snead, Method for analyzing passive silicon carbide thermometry with a continuous dilatometer to determine irradiation temperature, Nucl. Instruments Methods Phys. Res. Sect. B Beam Interact. with Mater. Atoms. 370 (2016) 49-58. doi:10.1016/j.nimb.2016.01.005.

[43] C. Lu, T. Koyanagi, Y. Katoh, G. Strydom, K.A. Terrani, N.R. Brown, Fully Ceramic Microencapsulated fuel in prismatic high-temperature gas-cooled reactors: Sensitivity of reactor behavior during design basis accidents to fuel properties and the potential impact of the SiC defect annealing process, Nucl. Eng. Des. 345 (2019) 125-147. doi:10.1016/j.nucengdes.2019.02.012.

[44] Y. Katoh, L.L. Snead, C.M. Parish, T. Hinoki, Observation and possible mechanism of irradiation induced creep in ceramics, J. Nucl. Mater. 434 (2013) 141-151.

doi:10.1016/j.jnucmat.2012.11.035. 